\title{
Selective antimicrobial activity of maggots against pathogenic bacteria
}

\author{
Domen Jaklič, ${ }^{1}$ Aleš Lapanje, ${ }^{1,2}$ Klemen Zupančič, ${ }^{1}$ Dragica Smrke ${ }^{3}$ \\ and Nina Gunde-Cimerman ${ }^{1}$ \\ ${ }^{1}$ Department of Biology, Biotechnical Faculty, University of Ljubljana, Večna pot 111, \\ 1000 Ljubljana, Slovenia \\ ${ }^{2}$ Institute of Physical Biology, Veliko Mlačevo 59, 1290 Grosuplje, Slovenia \\ ${ }^{3}$ University Medical Centre Ljubljana, Zaloška cesta 2, 1000 Ljubljana, Slovenia
}

Correspondence

Nina Gunde-Cimerman

nina.gunde-cimerman@bf.uni-lj.si

Received 16 July 2007

Accepted 21 January 2008

\begin{abstract}
Maggot therapy, also known as biosurgery, is an ancient method for the healing of chronic infected wounds. Although clinicians have reported on the beneficial activities of the Lucilia sericata larvae that have been used for healing chronic wounds, the selectivity of this therapy against the different pathogenic micro-organisms that are found in chronic wounds has never been analysed. In the present study, we have investigated the in vitro activities of larval excreta/ secreta both against selected bacterial strains that frequently occur in chronically infected wounds, and against bacteria isolated directly from the larvae and their excreta/secreta. Additionally, the antibacterial activities were investigated in in vivo studies, by comparing bacterial diversity in wounds before and after the application of $L$. sericata larvae. In conclusion, larval therapy is highly recommended, particularly for the treatment of wounds infected with Gram-positive bacteria, like Staphylococcus aureus, but less so for wounds infected with Gram-negative bacteria, especially Proteus spp. and Pseudomonas spp. strains. Bacteria from the genus Vagococcus were resistant to the maggot excreta/secreta.
\end{abstract}

\section{INTRODUCTION}

Maggot therapy, also known as biosurgery, is an ancient method for the healing of chronically infected wounds. Although the beneficial actions of fly larvae on wounds has long been known by the Australian aborigines (Lee, 1968) and by Central American Maya Indians (Weil et al., 1933), the maggots of the blow fly Lucilia sericata were first used clinically only five centuries later (Pechter \& Sherman, 1983). It was only after the appearance of bacterial strains with antibiotic resistance that maggot therapy was reintroduced for the second time in many hospitals in the USA and Europe (Sherman et al., 2000). Of particular interest was the finding that larval excreta/secreta are potent agents against meticillin-resistant Staphylococcus aureus (Bexfield et al., 2004).

Successful clinical experiences led to the initiation of several studies that have focused on the basic healing principles of maggot therapy. This healing can be attributed to the synergistic actions of four main activities: (i) the mechanical stimulation of wound drainage (Livingston \& Price, 1932; Weil et al., 1933) and the destruction of bacteria in the larval intestine (Greenberg, 1968; Lerch et al., 2003; Mumcuoglu et al., 2001), (ii) the enzymic degradation of necrotic tissue (Hobson, 1931; Vistnes et al., 1981), (iii) the antibacterial activity of maggot excreta/secreta (Bexfield et al., 2004; Livingston \& Price, 1932; Robinson \& Norwood, 1933; Simmons, 1935), and (iv) the stimulation of granulation tissue formation (Livingston \& Price, 1932; Prete, 1997; Robinson, 1935).

In terms of research, it is the antibacterial properties of the larval excreta/secreta that have been studied most extensively. Although in vitro studies of the antibacterial activities have revealed that they are potent against many pathogenic species of bacteria (Pavillard \& Wright, 1957; Robinson \& Norwood, 1933; Simmons, 1935; Vistnes et al., 1981), the effects of maggot therapy have not been determined for the diverse groups of micro-organisms that can infect chronic wounds.

The main focus of our investigation was thus to monitor bacterial diversity in the wounds of 30 patients in vivo, before and after the application of maggots. Additionally, selected species of bacteria were exposed to maggot excreta/secreta in vitro, and intrinsic bacterial resistance to the larval excreta/ secreta was investigated by isolating bacteria directly from the excreta/secreta and from the surface of non-sterile maggots. Based on the determined susceptibilities of the bacteria isolated and the selective actions on the bacteria present in a wound, the microbiological criteria for the selection of wounds that should be most appropriate for efficient healing with classical larval therapy were determined. 


\section{METHODS}

Preparation of sterile $L$. sericata larvae. Continuous cultures of $L$. sericata flies were maintained under $12 \mathrm{~h} / 12 \mathrm{~h}$ day/night cycles at room temperature under $60 \%$ humidity. To obtain embryos from the flies, a piece of beef liver was exposed to the flies for $2 \mathrm{~h}$. Oviposited eggs, containing the developing embryos, were transferred into sterile $0.5 \%$ sodium sulphite. After their dispersion in sodium sulphite, the eggs were immediately sterilized using the procedure described by Horn et al. (1976). The sterilized embryos were rinsed with sterile distilled water and incubated on blood agar plates for $11 \mathrm{~h}$ at $30{ }^{\circ} \mathrm{C}$. For their transportation and further experimental use, the sterile freshly hatched larvae were transferred to sterile containers.

Production of larval excreta/secreta. Approximately 500 2-3-dayold larvae were used for the collection of excreta/secreta. Over the $4 \mathrm{~h}$ needed for the collection, the larvae were rinsed every hour with $1 \mathrm{ml}$ distilled water. The crude excreta/secreta were filter-sterilized through $0.22 \mu \mathrm{m}$ filters. Their sterility and activity were tested on brain heart infusion (BHI) and blood agar plates (both from Biolife) as well as in liquid BHI media.

In vitro activity of larval excreta/secreta. The antibacterial activities of sterile larval excreta/secreta were tested on the K57 Escherichia coli strain, the V102 S. aureus strain and the K198 Pseudomonas aeruginosa strain, all of which were obtained from the Ex Culture Collection of the Biotechnical Faculty, University of Ljubljana, and also on the LM1 Vagococcus sp. strain, which was isolated from the collected larval excreta/secreta (see below) and deposited with the Ex Culture Collection. Bacterial cultures were grown in $25 \mathrm{ml} \mathrm{BHI} \mathrm{liquid} \mathrm{nutrient} \mathrm{medium} \mathrm{at} 37^{\circ} \mathrm{C}$ until a cell density of approximately $5 \times 10^{8}$ cells $\mathrm{ml}^{-1}$ was reached. Each culture was further diluted to $10^{4}$ and $10^{2}$ cells. From each bacterial dilution, $0.1 \mathrm{ml}$ was introduced into the test tubes containing $2 \mathrm{ml} \mathrm{BHI}$ and $2 \mathrm{ml}$ larval excreta/secreta. For positive growth control, $2 \mathrm{ml} 0.9 \%$ $\mathrm{NaCl}$ was added instead of the larval excreta/secreta, while for the negative control the tubes contained only $4 \mathrm{ml} 0.9 \% \mathrm{NaCl}$ and $0.1 \mathrm{ml}$ bacterial culture from previously prepared dilutions. Following an overnight incubation of the samples at $37{ }^{\circ} \mathrm{C}, 0.1 \mathrm{ml}$ was spread on BHI agar plates. Bacterial colonies were counted after 1 day of incubation at $37{ }^{\circ} \mathrm{C}$.

The duration of excreta/secreta antibacterial activity over time was also followed. The procedure was similar to that described above, with $0.1 \mathrm{ml}$ each sample spread over BHI agar plates every hour, over 9 hours. After overnight incubations at $37^{\circ} \mathrm{C}$, the bacterial colonies were counted.

Selection of patients. Seventeen female and thirteen male patients (total of thirty) were treated with classical applications of the larvae. Their wounds were classified according to Falanga (2000). The woundbed appearance was classified according of the percentage of granulation tissue as type A, B and C for $100,50-100$ and $<50 \%$ covered with granulation tissue, respectively. If any eschar was present, they were scored as type D. The wound exudates were graded as 1 if changes of the wound dressing were needed only weekly, as 2 if changes were required every 2-3 days and as 3 if they were required daily. The 30 patients with chronic wounds were classified according to Falanga (2000) as types B2 and C3. Further details are shown in Table 1.

Application of sterile larvae to the wounds. The larvae were administered within a cage-like dressing, as described by Sherman (1997). Briefly, a cage into which sterile larvae (5-8 larvae $\mathrm{cm}^{-2}$ ) were placed, was made of a ring of hydrocolloid (cut from Granuflex; ConvaTec) and Tegapore mesh (3M Health Care). The mesh was topped with a light gauze pad to absorb the necrotic drainage, which was replaced at least every $4-6 \mathrm{~h}$. The maggots were left in place
Table 1. Treated patients and their wounds

\begin{tabular}{|lc|}
\hline Clinical observation & $\begin{array}{c}\text { No. of wounds/ } \\
\text { patients }\end{array}$ \\
\hline Wound type & 1 \\
Venous ulcer & 14 \\
Arterial-venous combinations & 7 \\
Diabetic foot ulcers & 3 \\
Pressure ulcers & 5 \\
Postoperative chronic wounds & \\
Mobility of patient & 10 \\
Normal & 3 \\
Immobilized & 17 \\
On crutches & 13 \\
Patients with simultaneous antibiotic therapy & \\
\hline
\end{tabular}

within the cage dressing for 24 to $60 \mathrm{~h}$. With this protocol, 32 wounds of 30 patients were treated, since 2 patients developed additional secondary wounds during the study.

Bacteria identification in samples from wound tissue smears. Smears from the wounds and from larvae were taken separately before and after every single maggot application. They were placed in aerobic and anaerobic transportation media (Bibby Sterilin; Copan Innovation). Bacterial identification was based on standard methods used for the identification of clinically important isolates (Murray et al., 2003), and also on antibiograms performed at the Institute of Microbiology and Immunology at the Medical Faculty, University of Ljubljana, Slovenia.

Isolation and identification of the intrinsically excreta/secretaresistant bacterial strains. Bacterial strains that were resistant to the maggot excreta/secreta were isolated from non-sterile maggot macerates (4 maggots), from crude non-sterile maggot excreta/secreta $(5 \mathrm{ml})$ and from maggot food $(200 \mathrm{mg})$ previously exposed to maggots. For the isolation of these strains, all of the samples were exposed to $10 \mathrm{ml}$ sterile excreta/secreta diluted in BHI liquid medium (1:1), and then incubated at $30{ }^{\circ} \mathrm{C}$ for $24 \mathrm{~h}$. E. coli cultures (approximately $5 \times 10^{8}$ cells) were used as the positive control for excreta/secreta activity. Tenfold dilutions of incubated samples in $0.9 \% \mathrm{NaCl}$ solution were prepared, inoculated $(0.1 \mathrm{ml})$ on BHI plates and incubated until bacterial colonies appeared. Moreover, $50 \mathrm{ml}$ filter-sterilized excreta/secreta was incubated for 2 months at room temperature. In both cases, excreta/secreta-resistant bacteria were isolated and axenically reinoculated on new agar plates.

Isolation of DNA, sequencing and sequence manipulations. DNA was isolated with the Chelex (Bio-Rad)-based procedure, as described by Giraffa et al. (2000). The DNA isolated was used for PCR amplification with primers, according to Bianciotto et al. (1996). A 1495 bp long part of the $16 \mathrm{~S}$ rRNA gene was amplified and sequenced by Macrogene. The DNA sequences obtained were compared with those deposited in the RDPII database. DNA sequences were aligned using CLUSTAL_X software (Thompson et al., 1997) and manipulated using BioEdit software (Hall, 1999). Phylogenetic analysis was performed with Mega3 software (Kumar et al., 2004) with the neighbour-joining algorithm based on Kimura two-parameter matrices. Branches of the phylogenetic trees were tested with bootstrapping (1000 replications).

Statistic analyses. Statistical analyses were performed with the ANOVA and chi-square tests. 


\section{RESULTS}

One of the aims of the study was to determine the in vitro susceptibility and resistance of bacteria to maggot excreta/ secreta. Twelve Gram-negative bacterial strains (Table 2, Fig. 1) were isolated from non-sterile larvae that were grown on liver. Most of the isolates $(73 \%)$ were closely related to representatives of the genus Providencia and its relatives $(98-99 \%$ similarity). The remaining $27 \%$ belonged to the genera Proteus (98\% similarity to Proteus vulgaris and its relatives) and Pseudomonas (99\% similarity to Pseudomonas fluorescens and its relatives). Surprisingly, direct incubation of the maggot excreta/secreta resulted in the isolation of one Gram-positive strain, identified as Vagococcus lutrae (Table 2).

The effects of excreta/secreta added to solid BHI medium were not measurable (data not shown), while on liquid
BHI medium inhibitory effects on selected bacterial strain could be observed immediately. S. aureus (Fig. 2) completely stopped growing for up to $4 \mathrm{~h}$, and after $8 \mathrm{~h}$ of incubation the $S$. aureus cells could not be cultivated anymore. Incubation of maggot excreta/secreta with $E$. coli and $P$. aeruginosa cultures was less effective in terms of bactericidal activity; however, a prolonged lag phase that lasted for 5 to $6 \mathrm{~h}$ for both bacterial species was seen. After this temporary inhibition, normal growth was resumed. In all three bacterial species ( $S$. aureus, $E$. coli and $P$. aeruginosa), an inoculum-size-dependent inhibition was seen (ANOVA, $P<0.05$ ), while the growth of $V$. lutrae was not affected at all (data not shown).

Thirty treated patients received a total of fifty-one applications. For 20 wounds $(67 \%)$, the larvae were administered only once, for 10 wounds $(33 \%)$ an additional treatment followed the first one, for the wounds

Table 2. 16S rRNA sequence similarities between the larval excreta/secreta-resistant isolates and their three closest relatives, according to GenBank (National Center for Biotechnology Information)

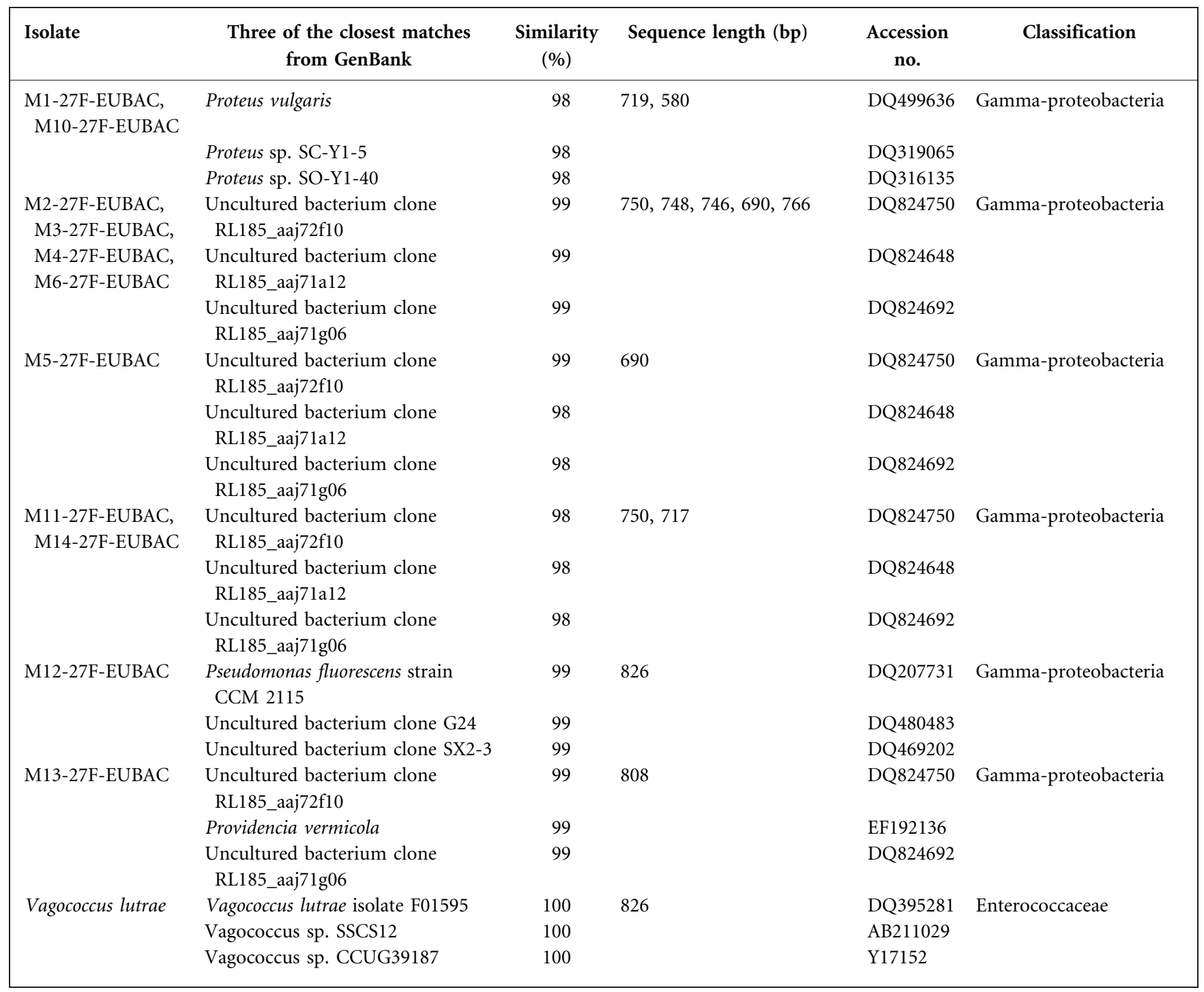




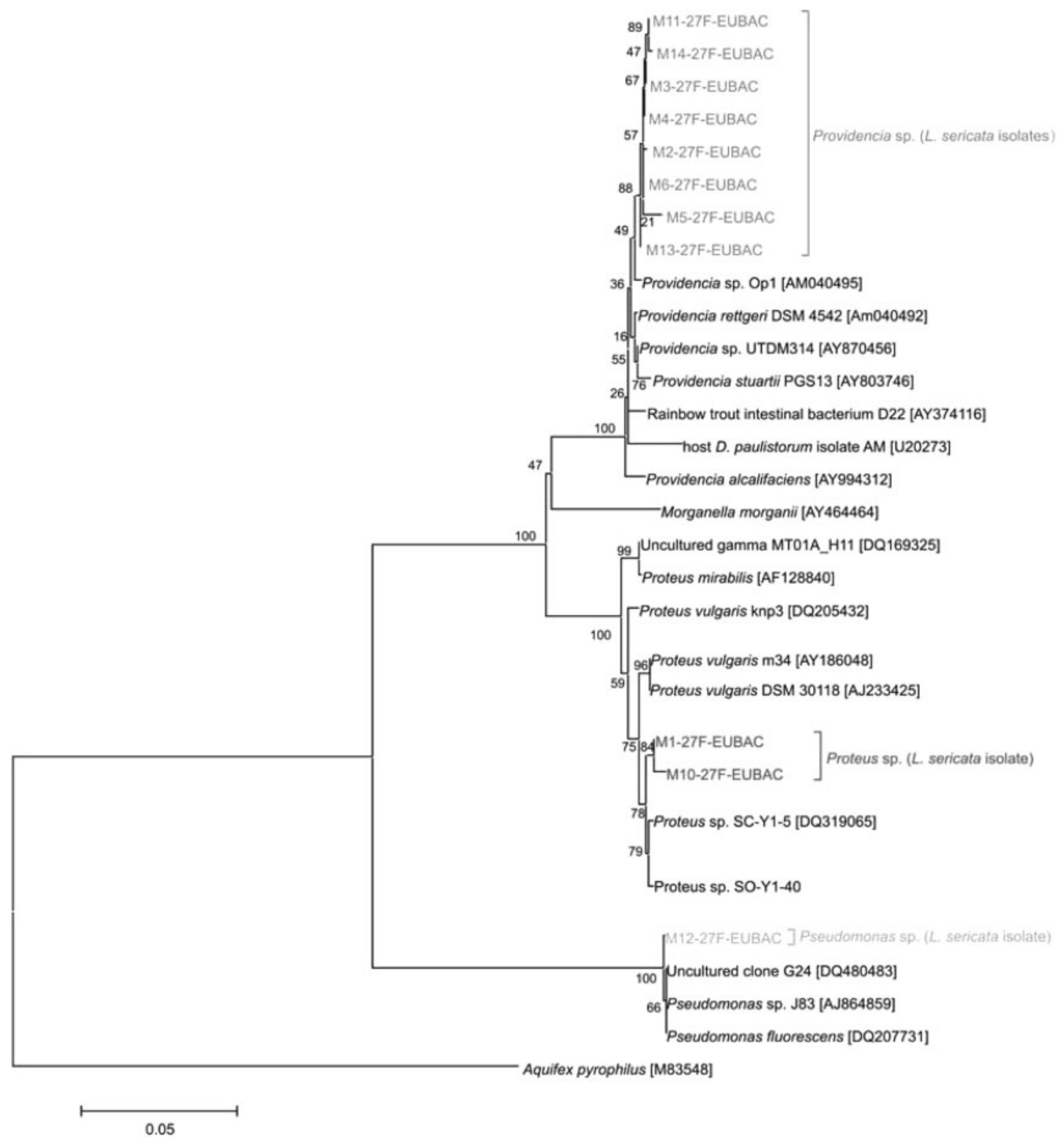

Fig. 1. Phylogenetic positions of the bacterial isolates from the larvae of $L$. sericata. The tree was constructed using the neighbour-joining method of Saitou \& Nei (1987) based on a Kimura two-parametric distance matrix. The bootstrap values (out of 1000 trees) are shown adjacent to the nodes.

of 2 patients the larvae were applied three times, and five applications were needed for 1 wound. All except one of the patients included in this study were medically examined after the wounds had healed. The maggot application was efficient in 30 cases $(83.2 \%$ ), with $6.6 \%$ of the treated wounds completely healed and $76.6 \%$ of the wounds not infected by pathogenic bacteria anymore. Healing with the maggots was effective in treating type B2 wounds as well as type C3. In 21 wounds that were cleaned with the larval therapy, spontaneous epithelialization occurred after additional dressings. A Thiersch graft was applied in four cases. With five patients, the larval therapy was interrupted because of the emergence of new disease with higher healing priority. The healing effects of larvae are depicted in Fig. 3, where a successfully healed foot is shown before and after 2 months of larval therapy.

The susceptibility of bacteria to maggot excreta/secreta was tested in vivo by monitoring the changes in the pathogenic bacterial diversity, and frequency, before and after the application of the sterile larvae to the wounds. The following pathogenic bacterial species were identified in the wounds before the treatment: coagulase-negative staphylococci, group C streptococci, group G streptococci, Bacteroides fragilis, Citrobacter freundii, Citrobacter koseri, Klebsiella oxytoca, Klebsiella spp., Peptococcus sp., Prevotella 


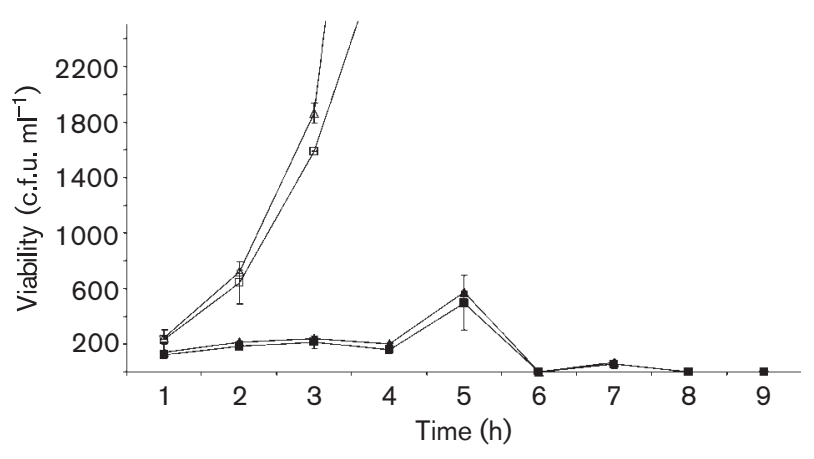

Fig. 2. In vitro activity of larval excreta/secreta on diluted cultures of $S$. aureus. Viability of bacterial cells was checked every hour with plate spreading of growing culture $(0.1 \mathrm{ml})$, while colonies were counted after overnight incubation at $37^{\circ} \mathrm{C}$. $\mathbf{\square}, 10^{-4} \mathrm{~S}$. aureus treated with excreta/secreta; $\square, 10^{-4} \mathrm{~S}$. aureus control; $\boldsymbol{\Lambda}, 10^{-5} \mathrm{~S}$. aureus treated with excreta/secreta; $\triangle, 10^{-5} \mathrm{~S}$. aureus control.

bivia, Proteus mirabilis, Proteus vulgaris, P. aeruginosa, Serratia marcescens, S. aureus and Streptococcus agalactiae (Table 3). After the application of the larvae, the total

(a)

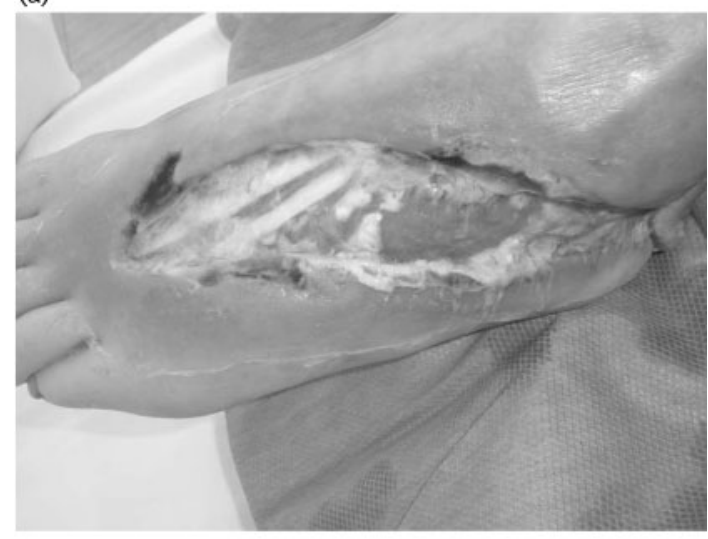

(b)

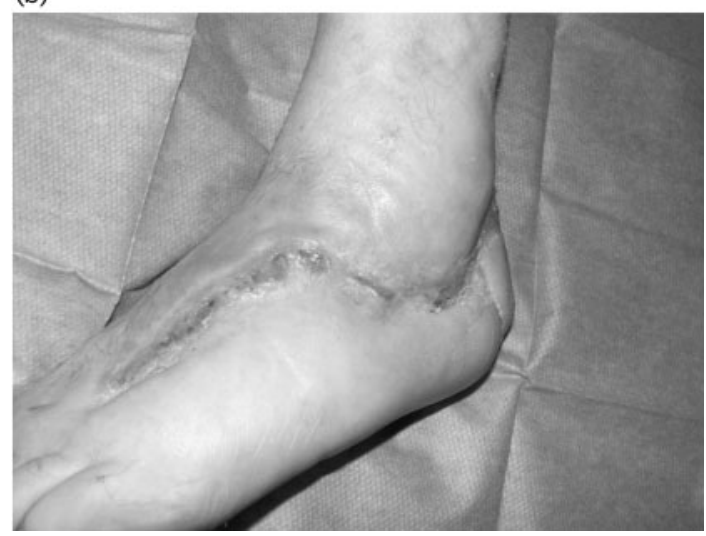

Fig. 3. Wound before treatment (a) and 2 months after completion of larval therapy (b).
Table 3. Bacterial susceptibility to larval excreta/secreta tested in vivo

The numbers in the before and after columns represent identified bacterial isolates from all wounds before the application of the sterile larvae and after larval treatment, respectively, while the ratio represents the increase/decrease in the number of certain species.

\begin{tabular}{|lccc|}
\hline & Before & After & Ratio \\
\hline Bacteroides fragilis & 2 & 0 & 0 \\
Citrobacter freundii & 1 & 0 & 0 \\
Citrobacter koseri & 2 & 1 & 0.5 \\
Diphtheroids & 4 & 6 & 1.5 \\
Enterococcus faecalis & 2 & 4 & 2 \\
Klebsiella oxytoca & 3 & 1 & 0.33 \\
Klebsiella pneumoniae & 1 & 1 & 1 \\
Klebsiella spp. & 1 & 0 & 0 \\
Morganella sp. & 1 & 2 & 2 \\
Peptococcus sp. & 2 & 0 & 0 \\
Peptostreptococcus asaccharolyticus & 0 & 1 & - \\
Porphyromonas sp. & 0 & 1 & - \\
Prevotella bivia & 1 & 0 & 0 \\
Proteus mirabilis & 4 & 4 & 1 \\
Proteus vulgaris & 1 & 1 & 1 \\
Providencia rettgeri & 0 & 1 & - \\
Pseudomonas aeruginosa & 10 & 8 & 0.8 \\
Serratia marcescens & 2 & 0 & 0 \\
Staphylococcus aureus & 11 & 7 & 0.64 \\
Coagulase-negative staphylococci & 5 & 2 & 0.4 \\
Stenotrophomonas maltophilia & 1 & 1 & 1 \\
Streptococcus agalactiae & 2 & 0 & 0 \\
a-Haemolytic streptococcus & 1 & 1 & 1 \\
Group C streptococci & 1 & 0 & 0 \\
Group G streptococci & 1 & 0 & 0 \\
Streptococcus pyogenes & 1 & 1 & 1 \\
Total & 61 & 43 & \\
& & & \\
\hline
\end{tabular}

number of species decreased for 14 wounds (63.6\%), while for 8 wounds $(33.3 \%)$ no differences were seen. This microbiological analysis of the wounds before and after the treatment was not carried out in 10 cases $(30.3 \%)$, while an increase in bacterial species was detected in only 1 case. Here, only Morganella morganii, a Gram-negative opportunistic invader, was found in one patient after the application of the sterile larvae (Table 3).

As well as from the isolates from wounds, bacteria were also isolated from the larvae used in the therapy. In $70 \%$ of cases (14 out of 20), differences in the bacterial species of the larvae and the bacterial species present in the wounds were detected after the treatment. In addition, in $20 \%$ of cases (4 out of 14), a difference in the ratio of the individual species was seen, although the species composition itself did not change. In 2 cases $(10 \%)$, there were no differences (Table 4).

Analysis of bacterial susceptibility to this maggot therapy (Table 3) showed bactericidal effects against group G streptococci, group C streptococci, B. fragilis, C. freundii, 
Table 4. Microbiological characterization of the efficiency of maggot therapy was determined by counting and identifying isolates before as well as after larval application

When microbiological tests were not performed according to the protocol, results were marked as not determined (ND). Microbiological characterization was also made to detect differences between the bacterial isolates from the wounds and isolates from the larvae used for the treatment of the same wounds: + , differences between the isolates from wound and larvae; $(+)$, same isolates from wound and larvae but with different ratios between the isolates. 0 , No differences; $\downarrow$, decreased number of species after treatment; $\uparrow$, increased number of species after treatment.

\begin{tabular}{|c|c|c|c|}
\hline $\begin{array}{l}\text { No. of } \\
\text { wound } \\
\text { treated }\end{array}$ & $\begin{array}{l}\text { No. of } \\
\text { applications for } \\
\text { individual } \\
\text { wounds }\end{array}$ & $\begin{array}{l}\text { Differences in no. of } \\
\text { bacterial species after } \\
\text { treatment }\end{array}$ & $\begin{array}{c}\text { Differences } \\
\text { between } \\
\text { larvae and } \\
\text { wounds }\end{array}$ \\
\hline 1 & 3 & $\downarrow$ & $\mathrm{ND}$ \\
\hline 2 & 3 & ND & + \\
\hline 3 & 1 & $\mathrm{ND}$ & $\mathrm{ND}$ \\
\hline 4 & 2 & $\mathrm{ND}$ & ND \\
\hline 5 & 2 & ND & ND \\
\hline 6 & 1 & $\downarrow$ & $\mathrm{ND}$ \\
\hline 7 & 1 & ND & $\mathrm{ND}$ \\
\hline 8 & 1 & $\mathrm{ND}$ & + \\
\hline 9 & 1 & $\mathrm{ND}$ & ND \\
\hline 10 & 2 & 0 & ND \\
\hline 11 & 2 & $\mathrm{ND}$ & $\mathrm{ND}$ \\
\hline 12 & 2 & ND & ND \\
\hline 13 & 5 & 0 & + \\
\hline 14 & 2 & $\downarrow$ & $(+)$ \\
\hline 15 & 1 & $\downarrow$ & + \\
\hline 16 & 2 & 0 & ND \\
\hline 17 & 1 & $\mathrm{ND}$ & + \\
\hline 18 & 1 & $\downarrow$ & + \\
\hline 19 & 1 & $\downarrow$ & + \\
\hline 20 & 2 & $\downarrow$ & + \\
\hline 21 & 2 & $\downarrow$ & + \\
\hline 22 & 2 & 0 & + \\
\hline 23 & 1 & 0 & 0 \\
\hline 24 & 1 & $\downarrow$ & + \\
\hline 25 & 1 & $\downarrow$ & $(+)$ \\
\hline 26 & 1 & $\downarrow$ & + \\
\hline 27 & 1 & $\downarrow$ & + \\
\hline 28 & 1 & 0 & $(+)$ \\
\hline 29 & 1 & 0 & 0 \\
\hline 30 & 1 & $\downarrow$ & $\mathrm{ND}$ \\
\hline 31 & 1 & $\downarrow$ & $\mathrm{ND}$ \\
\hline 32 & 1 & $\uparrow$ & $(+)$ \\
\hline 33 & 1 & 0 & + \\
\hline
\end{tabular}

Klebsiella spp., Peptococcus sp., Prevotella bivia, Serratia marcescens and Streptococcus agalactiae, all of which were not detected after the treatment. A considerable decrease in the incidence of five species was seen: coagulase-negative staphylococci, C. koseri, K. oxytoca, P. aeruginosa and S. aureus (Fig. 4). Surprisingly, six species increased in

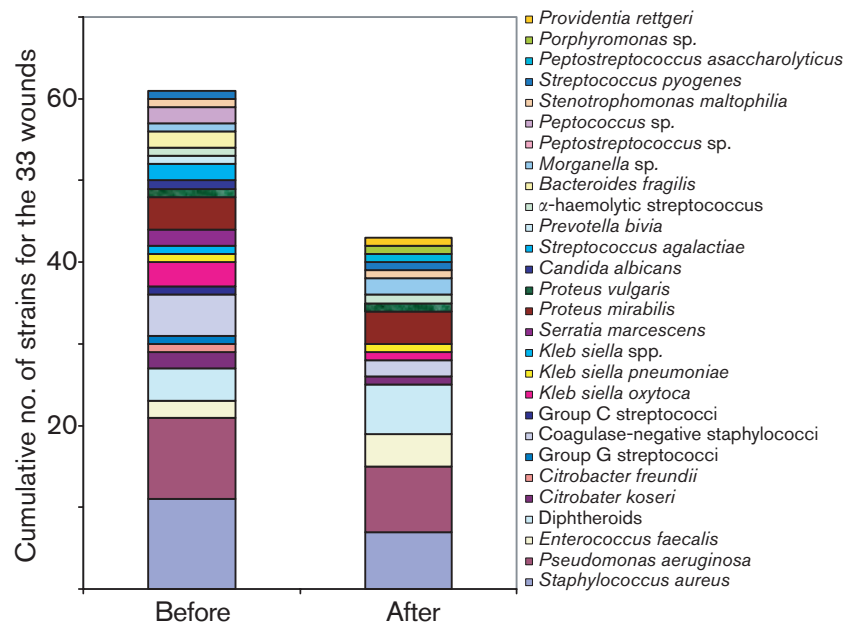

Fig. 4. Pathogenic bacteria in the wounds of the 30 patients before and after larval treatment.

occurrence as compared to the situation before the treatment: diphtheroids, Enterococcus faecalis, Morganella sp., Peptostreptococcus asaccharolyticus, Porphyromonas sp. and Providencia rettgeri. In Klebsiella pneumoniae, Proteus mirabilis, Proteus vulgaris, Stenotrophomonas maltophilia, $\alpha$-haemeolytic streptococcus and Streptococcus pyogenes we did not observe any considerable changes.

\section{DISCUSSION}

Nowadays, it is generally recognized that maggots can excrete a complex mixture of substances into a wound that can clean the wound and stimulate its healing. One aspect of the complex mode of action of this effect is the antibacterial activity. Despite several reports concerning such antibacterial properties (Greenberg, 1968; Pavillard \& Wright, 1957; Simmons, 1935; Thomas et al., 1999) and some attempts to determine what these antibacterial compounds are (Bexfield et al., 2004), the main components of this effective antimicrobial activity are still not known. However, it can be expected that several different antibacterial components, like oligopeptides (Bexfield et al., 2004), disinfectants (Erdmann \& Khalil, 1986) and low $\mathrm{pH}$ (Baer, 1931), act synergistically, as was proposed for Phormia terraenovae (Pavillard \& Wright, 1957). Moreover, some of these antibacterial components could also be synthesized by some of the maggots' gut commensals, as proposed by Greenberg (1968). Proteus mirabilis is one such commensal, indicating the general occurrence of members of the genus Proteus in flies of the family Calliphoridae. Therefore, if some bacteria present in the gut of the maggots survive the complex mode of maggot antibacterial action, some antibacterial selectivity of the excreta/secreta mix of substances would be expected. 
Since multiple factors are responsible for the antibacterial activity of maggot excretions, it is evident that the efficiency of the excreta/secreta, and hence of larval therapy, depends on one hand on the 'quality' of the maggots, and on the other hand on the microbiological and physico-chemical conditions present in their immediate environment.

To the best of our knowledge, there have been no reports on the diversity and susceptibility of bacteria present in the growth environment of the larvae, such as in larval feed, non-sterile maggot macerates and maggot excreta. Our study has revealed that several Gram-negative bacterial species, in addition to Proteus mirabilis, can colonize maggots; however, V. lutrae was the only Gram-positive strain that was isolated directly from the excreta/secreta. The bacteria isolated from the homogenized maggots were in the majority closely related to Providencia, and additionally to Proteus and Pseudomonas. Many strains of the genus Pseudomonas have developed multiple antibiotic resistances by acquiring resistant determinants and these are often responsible for long-term wound infections (Hsueh et al., 1998; Sekiguchi et al., 2005). Also, Pseudomonas, Proteus and Providencia can form biofilms and produce quorum-sensing signal molecules in the wounds (Schaber et al., 2004; Stickler et al., 1998), which present another barrier for the larvae to conquer. Pathogenic strains of Proteus mirabilis can also present a problem in wound infections, in spite of their potential antibacterial activity (Erdmann \& Khalil, 1986), since a plasmid-mediated antibiotic resistance was discovered in Proteus mirabilis (Wachino et al., 2006). It is noteworthy that Providencia rettgeri (previously known as Proteus rettgeri) produces an L-amino acid oxidase (Duerre \& Chakrabarty, 1975), which could act on the larval antibacterial oligopeptides. When $V$. lutrae (isolated from the maggot excreta/secreta) and the most frequent species infecting chronic wounds ( $S$. aureus, $P$. aeruginosa and $E$. coli) were exposed in liquid cultures to the maggot excreta/ secreta in vitro, we saw that the action on $S$. aureus was bactericidal, while no changes were seen for $V$. lutrae. Initially, the exposure of the selected bacteria to the maggot extracts was performed on solid media. It is of note that no antagonistic effects of the excreta/secreta on the bacterial cultures cultivated on solid media were seen, not even for S. aureus. Similar observations have already been reported in the literature (Bexfield et al., 2004; Pavillard \& Wright, 1957); although, some studies have identified activities against $S$. aureus cultivated on solid media (Kerridge et al., 2005). It appears that the preparation of excreta/secreta and the standardization of the media that are used for the determination of antibacterial activities could be important, as seen for the media used for MIC evaluation of antibacterial activities of conventional antibiotics (Murray et al., 2003).

Although in vitro bactericidal activities have been reported for larval excretions for individual species, including $S$. aureus (and also for meticillin-resistant S. aureus),
Streptococcus pyogenes, Enterococcus faecalis, 'Clostridium welchii, Proteus vulgaris, S. pneumoniae and E. coli (Bexfield et al., 2004; Kerridge et al., 2005; Lerch et al., 2003; Pavillard \& Wright, 1957; Simmons, 1935; Wolff \& Hansson, 1999), the effects of either sterile maggots or their excretions on mixed bacterial communities present in wounds (Bowler et al., 2001) have not been reported previously.

Infected wounds that harbour different bacterial communities represent a varied, natural environment for maggots, which changes after their application in a relatively consistent and repetitive pattern. Our statistically supported analyses of the microbial diversity of wounds revealed that the bacteria present can, in general, be divided into two main groups. The first group could be described as highly susceptible, since after the treatment its representatives either completely disappeared from the wounds or decreased considerably in occurrence. Within this group are E. coli, $P$. aeruginosa and $S$. aureus, for which high susceptibility has already been shown in other in vitro studies (Bexfield et al., 2004; Kerridge et al., 2005; Simmons, 1935). Some other human pathogens were also considerably affected: B. fragilis, C. freundii, C. koseri, K. oxytoca, Klebsiella spp., Peptococcus sp., Prevotella bivia, Serratia marcescens, coagulase-negative staphylococci, Streptococcus agalactiae, group $\mathrm{C}$ streptococci and group $\mathrm{G}$ streptococci.

The second group consists of bacteria that either remained unaffected or even increased in occurrence. This group consists mainly of Gram-negative, as well as selected Grampositive bacteria. It appears that the larvae have little effect on bacteria from Proteus spp, which we also isolated from maggot macerates. This might be due to either bacterial adaptation, or their symbiotic relationships as members of the $L$. sericata gut flora. It must be stressed that maggots have partially extracorporeal digestion. Therefore, an association of the bacteria with the animal might be already present outside the body, in the nearest animal environment, and may help in degradation of food particles (Chambers et al., 2003). Moreover, the bacteria that populate the environment close to the maggots might not be tolerated in such high densities inside the maggot gut, as shown by dissimilarities in the ratios of species present in/on the maggots as compared to the wounds.

As shown by in vitro studies and as demonstrated by the use of larvae enclosed in permeable Biobags (Grassberger \& Fleischmann, 2002), antibacterial components of maggot excretions are mainly responsible for the selective actions on different bacterial species present on wounds. However, it appears that the crawling and wandering of the larvae on the wounds can also considerably affect the bacteria, and particularly those that are anaerobic, that can form biofilms, that are less resistant to the passage through the larval intestine (Lehane, 1997) or that are generally less susceptible to the presence of antibiotic substances (Lerch et al., 2003; Mumcuoglu et al., 2001). The diminished action of antibiotics on bacterial biofilms is due to low 
diffusion, the thick extracellular matrix, co-existence of antibiotic-degrading bacteria and a low blood supply. The action of maggots can increase the microcirculation, and probably also destroy the very complex structure of a biofilm, consequentially exposing antibiotic-susceptible bacteria to the action of antibiotics (Costerton et al., 1994).

In certain cases, after the maggot application, the wounds were infected by bacterial species that were not present prior to the treatment. These could have been introduced from the microbial flora colonizing healthy skin around the wound (diphtheroids, coagulase-negative staphylococci, group $\mathrm{C}$ streptococci), due to the increased humidity below the bandage (Hutchinson \& Lawrence, 1991) or by the crawling of the larvae to the wound edges.

We can conclude that the bacterial diversity present in infected wounds is one of the factors that affect the success of larval therapy. This type of therapy is most appropriate for wounds infected with anaerobic and Gram-positive bacteria, while special precautions are needed when infections are due to Gram-negative bacterial species, and particularly with Proteus vulgaris and Proteus mirabilis.

\section{ACKNOWLEDGEMENTS}

The authors would like to acknowledge the help of Dr Parač in the application of the larvae and Dr Z. Arnež for introducing maggot therapy into the hospital (University Medical Centre, Ljubljana). The work was financed with a research grant from the Slovenian Research Agency (ARRS).

\section{REFERENCES}

Baer, W. S. (1931). The treatment of chronic osteomyelitis with the maggot (larva of the blowfly). J Bone Joint Surg Am 13, 438-475.

Bexfield, A., Nigam, Y., Thomas, S. \& Ratcliffe, N. A. (2004). Detection and partial characterisation of two antibacterial factors from the excretions/secretions of the medicinal maggot Lucilia sericata and their activity against methicillin-resistant Staphylococcus aureus (MRSA). Microbes Infect 6, 1297-1304.

Bianciotto, V., Bandi, C., Minerdi, D., Sironi, M., Tichy, H. V. \& Bonfante, P. (1996). An obligately endosymbiotic mycorrhizal fungus itself harbors obligately intracellular bacteria. Appl Environ Microbiol 62, 3005-3010.

Bowler, P. G., Duerden, B. I. \& Armstrong, D. G. (2001). Wound microbiology and associated approaches to wound management. Clin Microbiol Rev 14, 244-269.

Chambers, L., Woodrow, S., Brown, A. P., Harris, P. D., Phillips, D., Hall, M., Church, J. C. \& Pritchard, D. I. (2003). Degradation of extracellular matrix components by defined proteinases from the greenbottle larva Lucilia sericata used for the clinical debridement of non-healing wounds. Br J Dermatol 148, 14-23.

Costerton, J. W., Lewandowski, Z., DeBeer, D., Caldwell, D., Korber, D. \& James, G. (1994). Biofilms, the customized microniche. J Bacteriol 176, 2137-2142.

Duerre, J. A. \& Chakrabarty, S. (1975). L-amino acid oxidases of Proteus rettgeri. J Bacteriol 121, 656-663.

Erdmann, G. R. \& Khalil, S. K. (1986). Isolation and identification of two antibacterial agents produced by a strain of Proteus mirabilis isolated from larvae of the screwworm (Cochliomyia hominivorax) (Diptera: Calliphoridae). J Med Entomol 23, 208-211.

Falanga, V. (2000). Classifications for wound bed preparation and stimulation of chronic wounds. Wound Repair Regen 8, 347-352.

Giraffa, G., Rossetti, L. \& Neviani, E. (2000). An evaluation of Chelexbased DNA purification protocols for the typing of lactic acid bacteria. J Microbiol Methods 42, 175-184.

Grassberger, M. \& Fleischmann, W. (2002). The Biobag - a new device for the application of medicinal maggots. Dermatology 204, 306.

Greenberg, B. (1968). Model for destruction of bacteria in the midgut of blow fly maggots. J Med Entomol 5, 31-38.

Hall, T. A. (1999). BioEdit: a user-friendly biological sequence alignment editor and analysis program for Windows 95/98/NT. Nucleic Acids Symp Ser 41, 95-98.

Hobson, R. P. (1931). On an enzyme from blow-fly larvae (Lucilia sericata) which digests collagen in alkaline solution. Biochem J 25, 1458-1463.

Horn, K. L., Cobb, A. H., Jr \& Gates, G. A. (1976). Maggot therapy for subacute mastoiditis. Arch Otolaryngol 102, 377-379.

Hsueh, P. R., Teng, L. J., Yang, P. C., Chen, Y. C., Ho, S. W. \& Luh, K. T. (1998). Persistence of a multidrug-resistant Pseudomonas aeruginosa clone in an intensive care burn unit. J Clin Microbiol 36, 1347-1351.

Hutchinson, J. J. \& Lawrence, J. C. (1991). Wound infection under occlusive dressings. J Hosp Infect 17, 83-94.

Kerridge, A., Lappin-Scott, H. \& Stevens, J. R. (2005). Antibacterial properties of larval secretions of the blowfly, Lucilia sericata. Med Vet Entomol 19, 333-337.

Kumar, S., Tamura, K. \& Nei, M. (2004). MEGA3: integrated software for molecular evolutionary genetics analysis and sequence alignment. Brief Bioinform 5, 150-163.

Lee, D. J. (1968). Human myiasis in Australia. Med J Aust 1, 170-173.

Lehane, M. J. (1997). Peritrophic matrix structure and function. Annu Rev Entomol 42, 525-550.

Lerch, K., Linde, H.-J., Lehn, N. \& Grifka, J. (2003). Bacteria ingestion by blowfly larvae: an in vitro study. Dermatology 207, 362-366.

Livingston, S. K. \& Price, L. H. (1932). The treatment of chronic osteomyelitis with special reference to the use of the maggot active principle. J Am Med Assoc 98, 1143-1241.

Mumcuoglu, K. Y., Miller, J., Mumcuoglu, M., Friger, M. \& Tarshis, M. (2001). Destruction of bacteria in the digestive tract of the maggot of Lucilia sericata (Diptera: Calliphoridae). J Med Entomol 38, 161-166.

Murray, P. R., Baron, E. J., Jorgenson, J. H., Pfaller, M. A. \& Yolken, R. H. (2003). Manual of Clinical Microbiology, 8th edn. Washington, DC: American Society for Microbiology.

Pavillard, E. R. \& Wright, E. A. (1957). An antibiotic from maggots. Nature 180, 916-917.

Pechter, E. A. \& Sherman, R. A. (1983). Maggot therapy: the surgical metamorphosis. Plast Reconstr Surg 72, 567-570.

Prete, P. E. (1997). Growth effects of Phaenicia sericata larval extracts on fibroblasts: mechanism for wound healing by maggot therapy. Life Sci 60, 505-510.

Robinson, W. (1935). Stimulation of healing in non-healing wounds: by allantoin occurring in maggot secretions and of wide biological distribution. J Bone Joint Surg Am 17, 267-271.

Robinson, W. \& Norwood, V. H. (1933). The role of surgical maggots in the disinfection of osteomyelitis and other infected wounds. J Bone Joint Surg Am 15, 409-412.

Saitou, N. \& Nei, M. (1987). The neighbour-joining method: a new method for reconstructing phylogenetic trees. Mol Biol Evol 4, 406-425. 
Schaber, J. A., Carty, N. L., McDonald, N. A., Graham, E. D., Cheluvappa, R., Griswold, J. A. \& Hamood, A. N. (2004). Analysis of quorum sensing-deficient clinical isolates of Pseudomonas aeruginosa. J Med Microbiol 53, 841-853.

Sekiguchi, J.-i., Asagi, T., Miyoshi-Akiyama, T., Fujino, T., Kobayashi, I., Morita, K., Kikuchi, Y., Kuratsuji, T. \& Kirikae, T. (2005). Multidrugresistant Pseudomonas aeruginosa strain that caused an outbreak in a neurosurgery ward and its aac(6')-Iae gene cassette encoding a novel aminoglycoside acetyltransferase. Antimicrob Agents Chemother 49, 3734-3742.

Sherman, R. A. (1997). A new dressing design for use with maggot therapy. Plast Reconstr Surg 100, 451-456.

Sherman, R. A., Hall, M. J. R. \& Thomas, S. (2000). Medicinal maggots: an ancient remedy for some contemporary afflictions. Annu Rev Entomol 45, 55-81.

Simmons, S. W. (1935). A bactericidal principle in excretions of surgical maggots which destroys important aetiological agents of pyogenic infections. J Bacteriol 30, 253-267.

Stickler, D. J., Morris, N. S., McLean, R. J. C. \& Fuqua, C. (1998).

Biofilms on indwelling urethral catheters produce quorum-sensing signal molecules in situ and in vitro. Appl Environ Microbiol 64, 3486-3490.
Thomas, S., Andrews, A. M., Hay, N. P. \& Bourgoise, S. (1999). The anti-microbial activity of maggot secretions: results of a preliminary study. J Tissue Viability 9, 127-132.

Thompson, J. D., Gibson, T. J., Plewniak, F., Jeanmougin, F. \& Higgins, D. G. (1997). The CLUSTAL_X windows interface: flexible strategies for multiple sequence alignment aided by quality analysis tools. Nucleic Acids Res 25, 4876-4882.

Vistnes, L. M., Lee, R. \& Ksander, G. A. (1981). Proteolytic activity of blowfly larvae secretions in experimental burns. Surgery 90, 835-841.

Wachino, J.-i., Yamane, K., Shibayama, K., Kurokawa, H., Shibata, N., Suzuki, S., Doi, Y., Kimura, K., Ike, Y. \& Arakawa, Y. (2006). Novel plasmid-mediated 16S rRNA methylase, RmtC, found in a Proteus mirabilis isolate demonstrating extraordinary high-level resistance against various aminoglycosides. Antimicrob Agents Chemother 50, 178-184.

Weil, G. C., Simon, R. J. \& Sweadner, W. R. (1933). A biological, bacteriological and clinical study of larval or maggot therapy in the treatment of acute and chronic pyogenic infections. Am J Surg 19, 36-48.

Wolff, H. \& Hansson, C. (1999). Larval therapy for a leg ulcer with methicillin-resistant Staphylococcus aureus. Acta Derm Venereol 79, 320-321. 